Discussion Paper No. 07-045

Internationalizing R\&D Co-opetition: Dress for the Dance with the Devil

Anja Schmiele and Wolfgang Sofka

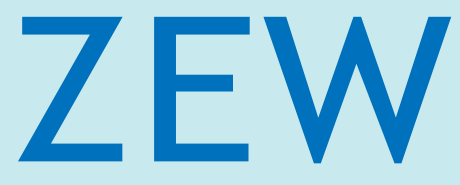

Zentrum für Europäische Wirtschaftsforschung $\mathrm{GmbH}$

Centre for European

Economic Research 
Discussion Paper No. 07-045

\title{
Internationalizing R\&D Co-opetition: Dress for the Dance with the Devil
}

\author{
Anja Schmiele and Wolfgang Sofka
}

Download this ZEW Discussion Paper from our ftp server:

ftp://ftp.zew.de/pub/zew-docs/dp/dp07045.pdf

Die Discussion Papers dienen einer möglichst schnellen Verbreitung von neueren Forschungsarbeiten des ZEW. Die Beiträge liegen in alleiniger Verantwortung der Autoren und stellen nicht notwendigerweise die Meinung des ZEW dar.

Discussion Papers are intended to make results of ZEW research promptly available to other economists in order to encourage discussion and suggestions for revisions. The authors are solely responsible for the contents which do not necessarily represent the opinion of the ZEW. 


\section{Non-technical summary}

The internationalization of firms shapes a new global competitive landscape in which firms are increasingly confronted with international competitors. The concept of co-opetition (cooperation and competition) follows the idea that competitors should not be seen purely as competitors in the battle for global market share. Instead, competitors can be valuable partners and sources of knowledge in a joint R\&D process. Competitors can offer more similarities than other market players since they operate in similar business environments and therefore develop similar processes and logics. Besides, a cooperative alliance with a competitor (coopetition) enables the firms to share uncertainties, costs and risks associated with the innovation process. In the paper we especially focus on co-opetition alliances between international competitors (international co-opetition) in the $\mathrm{R} \& \mathrm{D}$ process.

However, it is undeniable that such a cooperative alliance between competitors in the R\&D process has its risks. The main risk in a co-opetition alliance in the $R \& D$ process is the loss of expensive or unique firm knowledge which is one of the most valuable assets for a firm to create competitive advantage. Furthermore, the cooperation with a foreign competitor adds additional layers of risk and uncertainty to the management and outcomes of the alliance due to cultural differences which are embodied in the firm structure and organization processes. There might be different perceptions of trust as well as how cooperative innovation activities are performed in general. However, we argue that if the right capabilities are established in the firm than the benefits of an international R\&D co-opetition can outweigh the risks.

In order to prevent the undesired results of a R\&D co-opetition alliance we observed what it takes for a firm to be ready for a R\&D alliance with an international competitor. We question whether the methods for knowledge protection can be simply transferred from R\&D cooperations with a national competitor to cooperations with an international competitor. Besides, we survey which other abilities and international experience a firm should have to benefit from the international co-opetition alliance. We test our hypotheses for a broad sample of roughly 1,000 innovative firms in the German manufacturing sector. We find that coopetition with international competitors requires more pronounced protection methods for intellectual properties of the firm. Firms that are engaged in international co-opetition need to shift their appropriability practices from informal methods (secrecy, lead time) towards formal ones (patents and copyrights). Finally, we discover that the readiness for international co-opetition can be achieved by developing international collaboration experience through collaborations with international customers or suppliers. 


\title{
Internationalizing R\&D Co-opetition: Dress for the Dance with the Devil
}

\author{
Anja Schmiele and Wolfgang Sofka \\ Centre for European Economic Research (ZEW), Mannheim, Germany
}

\begin{abstract}
Competitors can be valuable sources and partners for innovation activities. Against the background of international expansion of firms and increased international competition, the R\&D collaborations with international competitors (international co-opetition) is becoming an increasingly interesting way to gain access to well guarded knowledge from abroad. However, to be able to benefit from these paradox alliances, a certain level of international co-opetition readiness is required. On the one hand, this readiness is important to protect the companies' intellectual property that should not be leaked to competitors. On the other hand, the firm has to be able to absorb and utilize the knowledge and capabilities of the collaborating competitor. Hence, we envision co-opetition as a balancing act between appropriability practices and absorptive capacities in a cross-border context. We test these dual hypotheses for a broad sample of roughly 1,000 innovative firms in the German manufacturing sector. We find that co-opetition with international competitors requires a shift in appropriability practices from informal methods (secrecy, lead time) towards formal ones (like patents and copyrights). Besides, we discover that the readiness for international co-opetition can be achieved by developing international collaboration experience through collaborations with international customers or suppliers.
\end{abstract}

Keywords: Co-opetition, R\&D collaboration, internationalization, innovation management JEL-Classification: F23, O31, O32, D83

Anja Schmiele

Schmiele@zew.de

Phone: +49/621/1235-188, Fax: +49/621/1235-170

Centre for European Economic Research (ZEW)

Department of Industrial Economics and International Management

P.O. Box 1034 43, D-68034 Mannheim, Germany

The authors thank Ulrich Kaiser, Thomas Ronde and Christian Rammer for invaluable comments and discussions. 


\section{$1 \quad$ Introduction}

Looking beyond company boundaries in innovation projects to share risks, costs and expertise is a major trend in innovation management discussions among both scholars and practitioners (see for example Chesbrough, 2003; Huston and Sakkab, 2006). Some companies even go as far as to cooperate with competitors (typically referred to as coopetiton) in innovation initiatives. This situation is as paradoxical as war and peace at the same time (Nalebuff and Brandenburger, 1996). Why would anyone voluntarily share with a competitor the very knowledge that could be the basis for future competitive advantage? Several studies have dealt with these co-opetitive cooperations, alliances or joint ventures (see for example Hamel, 1991). Our goal is to complement this literature by investigating a more focussed research question: What does it take to make a firm ready to move from domestic to foreign co-opetition?

The latter is especially relevant as globalization has resulted in firms finding themselves increasingly confronted with international competitors, on both domestic and foreign markets (Kleinschmidt and Cooper, 1988). We embed our argumentation in the resource and capability-based view of the firm and argue that organizational processes suitable for domestic co-opetition need to be refocused as firms move to the international stage. More precisely, we suggest that firms need to rethink the way in which they absorb and protect knowledge in international co-opetition. The latter is especially demanding as cultural and social barriers add additional levels of complexity and uncertainty. We develop hypotheses based on this core concept and test them empirically for a sample of about 1,000 manufacturing firms in Germany.

As our research question indicates, this study is designed to provide practitioners with guidance on how to "get international co-opetition ready." However, we also try to advance the academic discussion by investigating the organizational processes that facilitate the refocusing of existing capabilities to achieve a renewed fit within an internationalized environment.

The analysis is structured as follows: Following this introduction, section 2 provides the conceptual framework on co-opetition, which we develop further in the analytical section 3 to form hypotheses. Section 4 outlines the empirical study. The results of the estimation procedures are presented section 5 , while section 6 provides a discussion of the results, conclusions and management recommendations. 


\section{$2 \quad$ Establishing and Transferring Capabilities}

Our analysis focuses on the influence of the national and cultural environments on establishing capabilities and whether they can be successfully transferred across borders. Hence, we ground our theoretical investigation in the resource-based theory of the firm. This theory is built around the basic rationale that firms achieve sustainable competitive advantage through heterogeneously distributed resources that are valuable, rare and difficult for competitors to imitate or substitute (Barney, 1991; Conner, 1991; Penrose, 1959; Peteraf, 1993; Wernerfelt, 1984). Often possessing these resources is not enough - firms need to know how to use them (Collis and Montgomery, 1995; Penrose, 1959). This implies evaluating, manipulating and deploying them appropriately into unique combinations that enable specific actions for generating superior customer value and subsequent firm performance (Sirmon et al., 2007). This "bundling” of resources through organizational processes is typically referred to as a firm capability. Capabilities are cultivated in practice over time which makes them causally ambiguous as well as socially complex and hence difficult to copy or acquire on markets (Amit and Schoemaker, 1993; Dierickx and Cool, 1989).

We focus on the factors that shape these capabilities. The resource and capability-based view of the firm has been criticized for being overly concerned with resources internal to the firm and neglecting "when, where and how" they turn into competitive advantage (Priem and Butler, 2001). Sirmon et al. (2007) suggest a contingency logic to explain how resources are acquired and leveraged. They argue that environmental munificence and uncertainty shape capabilities. The goal is to achieve a fit with the environment. Munificent environments can support the growth of internal resources because access to external resources provides support (Baum and Wally, 2003). We extend this argumentation by relating it back to institution theory. As firms grow and develop within their home market, both the organization and its employees develop and refine certain skills, structures, practices and routines that reflect their social, cultural, economic and legal environment. Put simply, long-lasting exposure, experience and interaction produce a tailor-made entity that functions effectively and efficiently in the home market. This knowledge is largely acquired automatically at minimal extra costs. Substantial parts of these social and cultural laws are causally ambiguous and not codified (Jensen and Szulanski, 2004). Firms lose these certainties of their home market once they engage in international markets. They encounter cognitive uncertainty, i.e. uncertainty predicting and explaining the behaviour of others (Harvey and Novicevic, 2000). These frictional losses from cultural and social barriers have been summarized as liabilities of foreignness (Zaheer, 1995). ${ }^{1}$ The forces behind liability of foreignness are sociological in nature and have structural, relational and legitimacy dimensions (Zaheer, 2002). Differences in languages and hence understanding are a major but not exclusive factor (West and Graham, 2004). They translate into relative deficits in efficiency and effectiveness (Mezias, 2002). The visible symptoms of these challenges are more frequent errors, unnecessary risks and delays

$1 \quad$ It relates back to an earlier concept suggested by Hymer, 1976. 
(Lord and Ranft, 2000). These performance effects are as lasting as the liabilities of size and newness (Zaheer and Mosakowski, 1997). We explore whether capabilities developed in the home market can be transferred across national and cultural borders or if - and how - they need to be refocused. We investigate this research question in the very specific context of firms cooperating in innovation projects with competitors that have their headquarters abroad. 


\section{Co-opetition}

\subsection{A brief review of co-opetition research}

Cooperating with a competitor is a by its very nature a rather paradoxical act. The literature refers to this fusion of the two dichotomous conditions, cooperation and competition, as coopetition (Nalebuff and Brandenburger, 1996). More precisely, this means that two or more competitors cooperate at the same time as they compete (Luo, 2004). The idea of co-opetition builds on a changed view of competitors, moving from the traditional position that considers rivals purely as companies that endanger a company's market share with similar products and services towards a more open-minded position that also embraces complementary elements of competitors (Nalebuff and Brandenburger, 1996). Since firms do not compete across the whole range of their activities (Tether, 2002) competitors can be seen as valuable partners for building strategic alliances and realizing potential synergies (Luo, 2004). Co-opetition forms a window to the competitors' capabilities (Hamel et al., 1989) and does not only enable access to the skills of the collaborating competitor but also their assimilation (Hamel, 1991). The readiness of firms to engage in co-opetition depends on the firms' global experience, corporate culture, competitive goals, strategic orientation, competence complementarity, firm size and market power (Luo, 2004).

Then again, unique knowledge can be considered a firm's most valuable asset for generating competitive advantage (Liebeskind, 1996). It provides firms with the necessary platform to decide which resources or capabilities to deploy, develop or discard as their environment changes (Ndofor and Levitas, 2004). This perspective is typically summarized as the knowledge based view of the firm (Grant, 1996). An important stream of literature has dealt with the nature of knowledge as a "public good" that has to be kept proprietary as an incentive for firms to invest in its development (Jaffe, 1986; Porter Liebeskind, 1997). If this is the case, why should firms willingly let knowledge spill over to their competitors? Co-opetition in innovation activities and hence knowledge production can indeed be a mutually beneficial arrangement under certain circumstances.

Competing firms usually operate in a similar context and therefore develop a similar logic (Dussauge et al., 2000) which is a prerequisite for inter-partner learning (Hamel, 1991). The underlying motives for co-opetition in the field of $R \& D$ can be seen in the rapid changes in technologies that force innovative companies to recover their investments in shorter periods of time (Narula and Hagedorn, 1999). Hence, the most commonly named motives for collaborative R\&D activities with competitors are the consolidation of resources, cost and risk sharing during the innovation process as well as the establishment of a common standard in the industry (Tether, 2002). Several studies have dealt with structural forms of co-opetition, international strategic alliances and R\&D cooperations (see for example (Nalebuff and Brandenburger, 1996; Luo, 2004, Fritsch and Lukas, 2001). 
We attempt to extend this literature by focussing on a capability development perspective inside the co-opetiting firm. More precisely, we envision the capability to successfully engage in innovation cooperations with competitors as a balancing act: firms try to benefit as much as possible from incoming spillovers while limiting the outgoing ones. These competing learning incentives alter the relative bargaining power among partners (Hamel, 1991). What makes this arrangement especially fragile is that the co-opetiting partner has exactly the same incentives. The question of whether this very capability can be preserved as firms engage in co-opetition with foreign competitors is the core of this analysis.

\subsection{Internationalization of co-opetition}

Globalization is not a one-way street. As more new international markets emerge for domestic firms so do international competitors at home, or as Kleinschmidt and Cooper (1988), put it: “Our domestic market is someone else’s foreign market.” Globalization leads to increased global competition in many branches and therefore to a new dimension of coopetition: international co-opetition, cooperation between international competitors (Luo, 2007). While advances in information and telecommunications technology reduce the costs of coordinating and communicating across spatial distance, cultural and social barriers remain (Ghemawat, 2001; 2003). The latter are difficult to overcome as underlying norms and values on both sides of the border are typically unwritten and causally ambiguous (Jensen and Szulanski, 2004). These attributes make the transfer of co-opetition capabilities across borders difficult. Harvey and Novicevic (2000) introduce the concept of global organizational ignorance during cross border interactions, which covers such factors as the unawareness of relevant information and how to interpret it correctly. Managers rely on past experiences given the contextual ambiguity abroad (Dow, 2006). The underlying logic is derived from general decision making theory. Deciders rely on knowledge from the home market even when it is not fitting since it is more readily available, can be related back to a class of previous experiences and provides consistency with previous convictions (Harvey and Novicevic, 2000).

Hence, dealing with international partners not only exposes companies to culturally complex knowledge but also increases uncertainty. These attributes make knowledge difficult to transfer (Garud and Nayyar, 1994; Szulanski, 1996). Uncertainty makes the process less effective while the additional knowledge needed to understand complex items makes it less efficient. We argue that firms need to address both issues as they refocus their co-opetition capabilities from domestic towards international co-opetition.

\section{Complexity in international co-opetition}

Getting the most out of co-opetition engagements requires firms to sharpen their competencies and processes for spotting valuable knowledge and processing it. An important stream of research has conceptualized these processes as a firm's absorptive capacity (Cohen and Walsh, 2000). This consists of the identification of valuable knowledge in the environment, its assimilation with existing knowledge stocks and finally its exploitation for 
successful innovation. Absorptive capacities are the "eyes and ears" of a company to reinforce, complement or refocus their knowledge base (Lane et al., 2001). Cohen and Walsh (2000) stress the technological aspect of absorptive capacities and argue that the competencies to evaluate and exploit external knowledge are developed while performing $R \& D$ activities internally. We adopt their argument and suggest spotting technological opportunities is even more challenging as the complexities induced by international co-opetition increase. We argue:

Hypothesis I: Firms have to invest in technological absorptive capacities to engage in international co-opetition.

We extend this literature by arguing that absorptive capacities may not only stem from technological experience but also from international exposure. Firms may benefit from complementary resources and capabilities developed in related internationalization activities. Dyer and Singh (1998) introduces the idea of building absorptive capacity through collaboration and interaction between firms. Established relationships facilitate the detection of promising knowledge, as interaction precedents and shared understanding are already established (Laursen and Salter, 2006). An increase in the richness of transmission channels propels knowledge flows (Gupta and Govindarajan, 2000). Therefore, a firm's international exposure with regard to sales should provide complementary assets for succeeding in international co-opetition. Keller (2004) provides an excellent review on "learning by exporting." He concludes that studies in favor of this premise tend to be based on case studies while econometric analyses find no effect. We test whether this assessment holds for the specific circumstances of co-opetition and hypothesize:

Hypothesis IIa: Firms with high degrees of internationalization in sales are more likely to engage in international co-opetition.

Additionally, we suggest that the more specific experience of cooperating with international partners (apart from competitors) for innovation projects provides firms with processes and competencies that can be leveraged in international co-opetition. We propose:

Hypothesis IIb: Companies with other international innovation cooperations are more likely to engage in international co-opetition.

\section{Uncertainty in international co-opetition}

Beside the potential for inter-partner learning in innovation-orientated $R \& D$, both partners have a lot to lose from a co-opetition alliance. The natural uncertainty of the co-opetition alliance is grounded mainly in the fear that the competitor could access information that would endanger the market position of the firm. Such undesired behavior can result in a loss of expensive or unique firm knowledge that previously gave the firm a comparative advantage. In addition, it becomes more challenging to observe and explain the behavior of foreign partners in co-opetition (cognitive uncertainty; Harvey and Novicevic, 2000). The uncertainty in international firm alliances also stems from trust asymmetry between partners from different cultural environments. (Zaheer and Zaheer, 2006). Especially if trust is less embedded in a certain national context then in others, additional mechanisms have to 
compensate for the lack of trust (Zaheer and Zaheer, 2006). Having mentioned the risks of coopetition it becomes obvious that the control of knowledge flows during joint R\&D activities is a very important feature in successful innovation cooperations between competitors. The potential for appropriability in an alliance is therefore even higher when the partners are direct competitors (Seung Ho and Russo, 1996). The appropriability methods are grouped into formal appropriability methods and strategic appropriability methods (Rammer, 2002). Formal appropriability methods comprise legal ways of protection such as patents, copyrights and trade marks. They aim to prevent others from using the firm's patents and the knowledge associated with them but allow the competing firm to access the patent knowledge and to learn from it (Schmidt, 2006). Beside the formal methods, informal or strategic methods of knowledge non-disclosure exist which include secrecy, complex design, and lead time. Levin et al., 1987 showed in their study that secrecy and lead time were judged more effective in protecting new products and processes than patents. However, they also found that competitors incur higher costs and need more time to duplicate a firm's new products when the products and processes are patented. Veugelers (1998) investigated the knowledge protection behaviour of firms which have R\&D collaborations. Again, the study revealed that firms rate the effectiveness of informal mechanisms higher than patents or design registrations. In contrast to the formal legal protection, namely patents, informal appropriability methods are not defendable in court, which is a severe disadvantage. Both appropriability methods decrease knowledge spillovers to other firms (Schmidt, 2006). However, since partnering with an international competitor induces additional uncertainty, which is caused by additional cultural and social barriers, the joint R\&D activities take place under much more unpredictable and uncertain conditions. This additional uncertainty requires extended knowledge protection, in particular because certain knowledge which is embodied in machines and products can not be protected by secrecy (Schmidt, 2006). In areas where public knowledge access is strong, informal methods are less effective (Cohen and Walsh, 2000). Therefore we argue:

Hypothesis III: Firms move towards formal forms of appropriablity as they engage in international co-opetition. 


\section{$4 \quad$ Method}

\subsection{Data}

For the empirical part of this analysis we use cross section data from a survey on the innovation activities of German enterprises called the "Mannheim Innovation Panel" (MIP). The survey is conducted annually by the Centre for European Economic Research (ZEW) on behalf of the German Federal Ministry of Education and Research. The methodology and questionnaire used by the survey, which is targeted at enterprises with at least five employees, are the same as those used in the European Union's Community Innovation Survey (CIS). For our analysis we use the 2005 survey, in which data was collected on the innovation activities of enterprises during the three-year period 2002-2004. About 5,200 firms in manufacturing and services responded to the survey and provided information on their innovation activities. ${ }^{2}$ We utilize this data to operationalize the concepts presented above. Using CIS data has two major advantages. Firstly, heads of R\&D departments or innovation management are asked directly if and how they were able to generate innovations. Hence, they produce direct measures for processes and outputs which can complement traditional measures for innovation such as patents (Kaiser, 2002; Laursen and Salter, 2006). Secondly, the multinational application of CIS surveys adds extra layers of quality management and assurance. CIS surveys are subject to extensive pre-testing and piloting in various countries, industries and firms, to verify their interpretability, reliability and validity (Laursen and Salter, 2006).

\subsection{Variables}

\section{Dependent Variables}

Firms may cooperate with other firms for various reasons, e.g. joint production. Innovation activities may simply be a by-product of these engagements. In addition, a firm's perception of what other company within its industry should even be considered a direct competitor may vary. The latter would only be true for companies with similar resource endowments serving the same market needs (Bergen and Peteraf, 2002). Otherwise, they are just potential or indirect competitors. Our dataset does not force us to make any assumptions on these issues. The survey asks directly whether a firm engaged in innovation cooperations with competitors and where those were located. We generate our dependent variables based on these responses. Firms that cooperated with German competitors are designated as engaging in domestic co-

2 The sample was drawn using the stratified random sample technique. A comprehensive non-response analysis showed no systematic distortions between responding and non-responding firms with respect to their innovation activities. For a more detailed description of the dataset and the survey see Rammer, 2002. 
opetition, those with foreign competitors as engaging in international co-opetition. Both variables are binary in nature.

\section{Absorptive Capacity Variables}

Absorptive capacities are not a tangible concept but rather a combination of different competencies and capabilities. Hence, companies cannot be easily surveyed to estimate the degree to which they possess these absorptive capacities. Cohen and Walsh (2000) emphasize the rationale that absorptive capacities are developed by performing $R \& D$ activities. We follow their suggestion and introduce $R \& D$ intensity ( $\&$ D expenditure as a share of sales) to our model. Cohen and Walsh (2000) also emphasize the importance of prior experience. Hence, R\&D expenditures in any given year may not be as important as continuously accumulating stocks of knowledge. We incorporate this aspect by introducing a dummy variable indicating whether firms performed continuous R\&D activities. We also incorporate the employees' level of education and academic achievement (Rothwell and Dodgson, 1991), through the share of employees with academic education. Hypothesis I would be supported if the significant effects of all absorptive capacity variables are larger for international coopetition than domestic ones.

\section{Internationalization Variables}

We test Hypothesis IIa by introducing the share of exports in sales as well as two dummy variables indicating whether the firm is part of a multinational group with headquarters in Germany or abroad respectively. The significant effects of these variables should be larger for international than for domestic co-opetition to support the hypothesis. Furthermore, we capture the effect of international cooperation experience as a positive prerequisite for international co-opetition suggested in Hypothesis IIb. We add two dummy variables for existing cooperations of firms with international suppliers and international customers respectively to test the hypothesis. The significant effects for international co-opetition should exceed domestic ones.

\section{Appropriability Variables}

Several studies rely only on the importance of formal methods of appropriability (especially patents) because they are more easily traceable. Our survey also allows us to track the availability of informal mechanisms for appropriating knowledge in a firm and their importance. These may be based on organizational practices (secrecy, lead time) or inherent in the product (complex design). Hence, we add variables for all three forms of appropriability where firms ranked the importance of the various forms as high. Hence, we add dummy variables for all three forms of appropriability. Hypothesis III would be supported if significant effects of formal appropriability methods outweigh informal ones in international co-opetition. 


\section{Control Variables}

We control for several other factors that may influence the estimation results of our core variables. We have no a-posteriori assumptions on their outcomes. We include control variables for firm size (no. of employees) and regional differences within Germany (firm location in East Germany). More importantly, we control whether a firm has received public funding for its innovation activities during our observation period from the European Union or the German federal or state governments, following the rationale that cross border innovation alliances may be (co-)funded by the German state. Public funding programs in Germany have moved towards a network approach since the 1980s, favoring project consortia over individual recipients to promote knowledge spillovers (for a review see Fier and Harhoff, 2002). Hence, the decision to cooperate with a competitor for innovation activities may be influenced by the prospect of public funding and not follow our theoretical argumentation as outlined above. The dummy variable is introduced to control for this effect.

Besides, firms may choose different approaches for their cooperation engagements based on firm specific goals and perceived shortages. Aschhoff and Schmidt (2006) identify two broad motives: cost/risk sharing and knowledge seeking. We add two dummy variables indicating whether a firm perceived high cost/risks as a dominant obstacle to its innovation activities and whether it did so based on a lack of technological and/or market information.

Finally, we add two industry dummy variables (medium high-tech manufacturing, high-tech manufacturing) to capture remaining industry specific differences.

\subsection{Descriptive statistics}

Out of the 5,200 firms in manufacturing and services sector that responded to the survey, we derive a final sample of 956 firms in the manufacturing sector of Germany which have innovation activities and show no missing values for any model variables. Out of this range of firms we found 47 companies that cooperated with foreign competitors and 74 had cooperations with domestic competitors. A detailed list of the descriptive statistics can be found in Table 1. Several firms engage both in domestic and in foreign co-opetition. Firms engaged in international co-opetition are larger than firms that choose domestic co-opetition and invest a higher share of their sales in $R \& D$. However, they conduct continuous $R \& D$ activities less frequently. Firms that undertake international co-opetition are also more extensively involved in cooperation with international suppliers (34\%) and international customers (53\%). Among firms that engage in domestic co-opetition, only 19\% cooperate with international suppliers, and 26\% with international customers. 
Table 1: Descriptive Statistics

\begin{tabular}{|c|c|c|c|c|}
\hline \multirow[b]{2}{*}{ Variables } & \multicolumn{2}{|c|}{$\begin{array}{l}\text { Domestic } \\
\text { Co-opetition } \\
\end{array}$} & \multicolumn{2}{|c|}{$\begin{array}{l}\text { International } \\
\text { Co-opetition } \\
\end{array}$} \\
\hline & Mean & Std. Dev. & Mean & Std. Dev. \\
\hline Domestic Co-opetition & 1.00 & $(0.00)$ & 0.40 & $(0.50)$ \\
\hline International Co-opetition & 0.26 & $(0.44)$ & 1.00 & $(0.00)$ \\
\hline Number of Employees & 667.08 & $(1,122.85)$ & $1,886.09$ & $(6,503.48)$ \\
\hline $\begin{array}{l}\text { Share of Employees with higher education } \\
\text { (\%) }\end{array}$ & 0.23 & $(0.20)$ & 0.24 & $(1.17)$ \\
\hline R\&D Expenditure as a share of Sales (\%) & 0.07 & $(0.10)$ & 0.05 & $(0.07)$ \\
\hline $\begin{array}{l}\text { Continous R\&D activities (dummy) } \\
\text { Appropriability: Patents, Copyrights }\end{array}$ & 0.80 & $(0.40)$ & 0.85 & $(0.36)$ \\
\hline $\begin{array}{l}\text { (dummy) } \\
\text { Appropriability: Secrecy, Lead time }\end{array}$ & 0.53 & $(0.50)$ & 0.79 & $(0.41)$ \\
\hline (dummy) & 0.73 & $(0.45)$ & 0.72 & $(0.45)$ \\
\hline Appropriability: Complex design (dummy) & 0.12 & $(0.33)$ & 0.17 & $(0.38)$ \\
\hline $\begin{array}{l}\text { MNE with Headquarters abroad (dummy) } \\
\text { MN Group with domestic Headquarters }\end{array}$ & 0.12 & $(0.33)$ & 0.21 & $(0.41)$ \\
\hline (dummy) & 0.24 & $(0.43)$ & 0.30 & $(0.46)$ \\
\hline Exports as a share of Sales (\%) & 31.68 & $(26.34)$ & 41.39 & $(26.02)$ \\
\hline $\begin{array}{l}\text { Obstacle: Cost/Risk (dummy) } \\
\text { Obstacle: Lack of technological / market } \\
\text { knowledge (dummy) }\end{array}$ & $\begin{array}{l}0.36 \\
0.05\end{array}$ & $\begin{array}{l}(0.48) \\
(0.23)\end{array}$ & $\begin{array}{l}0.40 \\
0.09\end{array}$ & $\begin{array}{l}(0.50) \\
(0.28)\end{array}$ \\
\hline $\begin{array}{l}\text { Public funding for innovation (dummy) } \\
\text { Company located in East Germany }\end{array}$ & 0.65 & $(0.48)$ & 0.64 & $(0.49)$ \\
\hline $\begin{array}{l}\text { (dummy) } \\
\text { Medium High Tech Manufacturing }\end{array}$ & 0.39 & $(0.49)$ & 0.19 & $(0.40)$ \\
\hline Industry (dummy) & 0.32 & $(0.47)$ & 0.45 & $(0.50)$ \\
\hline & 0.24 & $(0.43)$ & 0.19 & $(0.40)$ \\
\hline $\begin{array}{l}\text { Cooperation with international Supplier } \\
\text { (dummy) }\end{array}$ & 0.19 & $(0.39)$ & 0.34 & $(0.48)$ \\
\hline $\begin{array}{l}\text { Cooperation with international Customer } \\
\text { (dummy) }\end{array}$ & 0.25 & $(0.44)$ & 0.53 & $(0.50)$ \\
\hline Observations & 74 & & 47 & \\
\hline
\end{tabular}

\subsection{Method}

The decisions to cooperate with domestic or foreign competitors in innovation activities are not independent of one another. Firms may simultaneously engage in both, selectively in one or none at all. Because of this we model each decision (domestic and international coopetition) separately. We tested a bivariate probit approach that would assume that both decisions are related and that information captured in one equation could be used to improve the efficiency of the other, and vice versa (methodologically we allow the error terms of both equations to be correlated, for more details see Greene, 2002). The correlation of both error terms is positive but not significant, which implies that we are dealing with largely 
independent decisions. Accordingly, we return to standard probit models and estimate one separately for each decision. Correlation between the variables on cooperation with foreign suppliers and customers prevents us from estimating them jointly. Hence, they are introduced to the models separately.

In addition, we calculate and report marginal effects. They reflect the effect of an infinitesimal change in each independent variable (from 0 to 1 in case of a dummy variable) on the probability of a positive decision to engage in domestic or international co-opetition. This allows us to compare effects and therefore to test our conceptual hypotheses. 


\section{$5 \quad$ Results}

In Hypothesis I we suggest that firms need to invest in superior absorptive capacities for international co-opetition. This Hypothesis has to be rejected. The empirical results presented in Table 2 show that the share of employees who have completed higher education has significant effects for both domestic and international co-opetition. This indicates that individual skillsets are the dominant component of absorptive capacities in co-opetition. However, the effects for domestic co-opetition are stronger. This result is especially surprising as one would assume that educated employees possess superior language skills. Besides, we find that continuous R\&D activities are more valuable in firms that undertake domestic co-opetition. This may indicate that accumulated stocks of knowledge are not as important in international co-opetition as they are in national co-opetition.

Hypothesis IIa has to be rejected, too. There is no significant "learning-by-exporting” effect in international co-opetiton, which supports the more general results of Keller, 2004 on international knowledge diffusion. Multinational group variables also produce no significant effects. However, Hypothesis IIb can be accepted. International cooperation experience with suppliers and customers enhance the likelihood of cooperating with competitors, both locally and internationally. Our results demonstrate that international cooperation experience has a far greater effect on international co-opetition than on domestic co-opetition. Hence, international cooperation experience propels both forms of co-opetition but the experience is much more valuable to international engagements.

Hypothesis III can be accepted. Our proposition that international co-opetition requires more formal appropriability methods is supported. While secrecy and lead time are well established appropriability methods in domestic co-opetition we find that these forms of informal knowledge protection are not significant for international co-opetition. Firms dealing with international co-opetition partners rely on formal methods like patents. There is an isolated negative, significant effect from complex product design on domestic co-opetition indicating that additional layers of complexity make domestic co-opetition less attractive.

With an eye on control variables, we identify a positive firm size effect on the probability of engaging in domestic co-opetition. This relationship is linear as the squared term of the number of employees is not significant. Besides, public funding for innovation projects has the outlined positive and significant effect on firm's decisions to engage in co-opetition. It increases the likelihood of domestic co-opetition by $11 \%$ and of international by $3 \%$. Given the magnitude of this effect it proves to be an important control variable. 
Table 2: Results from probit estimation: Marginal effects

\begin{tabular}{|c|c|c|c|c|c|c|c|c|}
\hline \multirow[b]{3}{*}{ Variables } & \multicolumn{4}{|c|}{ Model 1} & \multicolumn{4}{|c|}{ Model 2} \\
\hline & \multicolumn{2}{|c|}{ Domestic Co-opetition } & \multicolumn{2}{|c|}{ International Co-opetition } & \multicolumn{2}{|c|}{ Domestic Co-opetition } & \multicolumn{2}{|c|}{ International Co-opetitior } \\
\hline & Marginal Effect & Std. Err. & Marginal Effect & Std. Err. & Marginal Effect & Std. Err. & Marginal Effect & Std. Err. \\
\hline \multicolumn{9}{|l|}{ Hypothesis I } \\
\hline Share of Employees with higher education (\%) & $0.06^{* *}$ & $(0.03)$ & $0.02^{* *}$ & $(0.01)$ & $0.05^{* *}$ & $(0.03)$ & $0.02^{* *}$ & $(0.01)$ \\
\hline R\&D Expenditure as a share of Sales (\%) & 0.00 & $(0.01)$ & -0.02 & $(0.02)$ & 0.00 & $(0.01)$ & -0.05 & $(0.03)$ \\
\hline Continous R\&D activities (dummy) & $0.04^{* * *}$ & $(0.02)$ & 0.00 & $(0.01)$ & $0.05^{* * *}$ & $(0.02)$ & 0.01 & $(0.01)$ \\
\hline \multicolumn{9}{|l|}{ Hypothesis IIa } \\
\hline Exports as a share of Sales (\%) & 0.00 & $(0.00)$ & 0.00 & $(0.00)$ & 0.00 & $(0.00)$ & 0.00 & $(0.00)$ \\
\hline MNE with Headquarter abroad (dummy) & -0.01 & $(0.01)$ & 0.00 & $(0.00)$ & -0.01 & $(0.01)$ & 0.00 & $(0.00)$ \\
\hline MN Group with domestic Headquarter (dummy) & 0.01 & $(0.02)$ & 0.00 & $(0.00)$ & 0.00 & $(0.02)$ & 0.00 & $(0.00)$ \\
\hline \multicolumn{9}{|l|}{ Hypothesis IIb } \\
\hline Cooperation with international Supplier (dummy) & $0.22^{* *}$ & $(0.10)$ & $0.34^{* * *}$ & $(0.12)$ & & & & \\
\hline Cooperation with international Customer (dummy) & & & & & $0.20^{* *}$ & $(0.09)$ & $0.32^{* * *}$ & $(0.11)$ \\
\hline \multicolumn{9}{|l|}{ Hypothesis III } \\
\hline Appropriability: Secrecy, Lead time (dummy) & $0.02^{*}$ & $(0.01)$ & 0.00 & $(0.00)$ & $0.02^{*}$ & $(0.01)$ & 0.00 & $(0.00)$ \\
\hline Appropriability: Complex design (dummy) & $-0.02^{* *}$ & $(0.01)$ & 0.00 & $(0.00)$ & -0.02 & $(0.01)$ & 0.00 & $(0.00)$ \\
\hline Company located in East Germany (dummy) & 0.02 & $(0.01)$ & 0.00 & $(0.00)$ & 0.02 & $(0.01)$ & 0.00 & $(0.00)$ \\
\hline No. of employees (in logs) & $0.03^{*}$ & $(0.02)$ & 0.00 & $(0.01)$ & $0.03^{*}$ & $(0.02)$ & 0.00 & $(0.01)$ \\
\hline Squared No. of employees (in logs) & 0.00 & $(0.00)$ & 0.00 & $(0.00)$ & 0.00 & $(0.00)$ & 0.00 & $(0.00)$ \\
\hline Medium High Tech Manufacturing Industry (dummy) & 0.01 & $(0.01)$ & 0.01 & $(0.01)$ & 0.00 & $(0.01)$ & 0.01 & $(0.01)$ \\
\hline High Tech Manufacturing Industry (dummy) & 0.01 & $(0.02)$ & 0.00 & $(0.01)$ & 0.01 & $(0.02)$ & 0.00 & $(0.01)$ \\
\hline Obstacle: Cost/Risk (dummy) & 0.01 & $(0.01)$ & 0.01 & $(0.01)$ & 0.01 & $(0.01)$ & 0.01 & $(0.01)$ \\
\hline $\begin{array}{l}\text { Obstacle: Lack of technological / market knowledge } \\
\text { (dummy) }\end{array}$ & -0.01 & $(0.02)$ & 0.00 & $(0.01)$ & -0.01 & $(0.02)$ & 0.01 & $(0.01)$ \\
\hline Public funding for innovation (dummy) & $0.11^{* * *}$ & $(0.03)$ & $0.03^{* *}$ & $(0.01)$ & $0.11^{* * *}$ & $(0.03)$ & $0.03^{* *}$ & $(0.01)$ \\
\hline Adj Count R2 & \multicolumn{2}{|c|}{0.095} & \multicolumn{2}{|c|}{0.277} & \multicolumn{2}{|c|}{0.041} & \multicolumn{2}{|c|}{0.319} \\
\hline
\end{tabular}

*significant at $10 \%$; ** significant at $5 \%$; *** significant at $1 \%$; constant term included;

for dummy variables: marginal effect for discrete change from 0 to 1 


\section{Discussion}

We position co-opetition theoretically as a firm capability that can be transferred across national and cultural borders. Still, we hypothesize that firms need to refocus their underlying processes developed in a national environment to be ready for international co-opetition.

International cooperation experience with other firms (customers, suppliers) enables firms to develop certain processes and competences that enable international co-opetition activities. We suggest that international cooperation allows firms to develop a unique understanding and the necessary confidence for dealing with international competitors. They provide the firm with insights into more complex and uncertain partnerships incorporating cross cultural backgrounds. The attitudes of "cooperating” and "sharing” are also helpful for engaging in domestic co-opetition but much more fruitful in an international context. Interestingly, international cooperation experience is specific and cannot be replicated by simply exporting goods and services. We suspect that the sensitivity for foreign markets deriving from exports is largely developed in marketing and sales departments but does not reach R\&D units.

It does not come as a surprise that skilled employees support international co-opetition but this effect is weaker compared to domestic co-opetition. We suspect that this is the result of a lack of personal networks across borders. These networks have been identified as important channels for knowledge flows. These may stem from personnel mobility, that shapes interpersonal networks and even co-ethnicity (Agrawal et al., 2006; Kalnins and Chung, 2006; Singh, 2005). This social capital (Adler and Kwon, 2002) may only be more readily available within national and cultural borders. This may be especially relevant as we empirically investigate Germany.

Furthermore, we find an important shift in the way companies control their existing knowledge when moving from domestic to international co-opetition. While informal appropriability mechanisms may be sufficient in the home environment they move towards formal ones (patents) in an international context. Apparently, this provides them with the means to make the relevant knowledge visible, traceable and defendable.

Returning to our initial research question: How do firms get "international co-opetition ready?” We cannot recommend a general strengthening of absorptive capacities. We suggest that firms need to develop processes, structures and skillsets which provide cultural sensitivity. These are most promisingly found where firms have already cooperated with international customers and suppliers. Lessons can and should be drawn from these experiences. What is more, there is a need to switch from informal modes of appropriability to formal ones. We cannot infer from our analysis whether this is just the legal expertise to apply for and litigate patents. Some studies have suggested that patents are also an important channel for the controlled release of knowledge (embodied in the patent) into the public domain. The latter may imply a more thorough reconfiguration of processes and attitudes from secrecy/lead time to controlled patenting. 


\section{$7 \quad$ Limitations and further research}

Our study faced certain limitations that have to be acknowledged and may provide fruitful avenues for future research. First, we benefit from a high quality, extensive dataset. Still, it was not specifically designed for the particular purpose of this study. Hence, some measures, especially those which look at the degree of internationalization, are rather crude. Second, we focus empirically on Germany with its unique economic and cultural roots and circumstances. Comparative international studies would provide valuable additional insights. Third, we rely on a cross sectional dataset. Several of our claims can only be fully substantiated by a longitudinal analysis. Fourth, we investigate "actual" not "best" practices of co-opetition. Whether these are profitable may be a different issue. 


\section{$8 \quad$ Appendix}

\section{Appendix A: Industry breakdown}

\begin{tabular}{|l|l|l|}
\hline Industry & NACE Code & Industry Group \\
\hline Mining and quarrying & $10-14$ & Other manufacturing \\
\hline Manufacture of food and tobacco & $15-16$ & Other manufacturing \\
\hline $\begin{array}{l}\text { Manufacture of textiles and } \\
\text { leather }\end{array}$ & $17-19$ & Other manufacturing \\
\hline $\begin{array}{l}\text { Manufacture of wood / paper / } \\
\text { publishing }\end{array}$ & $20-22$ & Other manufacturing \\
\hline $\begin{array}{l}\text { Manufacture of chemicals / } \\
\text { petroleum }\end{array}$ & $23-24$ & $\begin{array}{l}\text { Medium high-tech } \\
\text { manufacturing }\end{array}$ \\
\hline Manufacture of plastic / rubber & 25 & Other manufacturing \\
\hline Manufacture of glass / ceramics & 26 & Other manufacturing \\
\hline Manufacture of metal & $27-28$ & Other manufacturing \\
\hline $\begin{array}{l}\text { Manufacture of machinery and } \\
\text { equipment }\end{array}$ & 29 & $\begin{array}{l}\text { Medium high-tech } \\
\text { manufacturing }\end{array}$ \\
\hline $\begin{array}{l}\text { Manufacture of electrical } \\
\text { machinery }\end{array}$ & $30-32$ & High-tech manufacturing \\
\hline $\begin{array}{l}\text { Medical, precision and optical } \\
\text { instruments }\end{array}$ & 33 & High-tech manufacturing \\
\hline Manufacture of motor vehicles & $34-35$ & $\begin{array}{l}\text { Medium high-tech } \\
\text { manufacturing }\end{array}$ \\
\hline $\begin{array}{l}\text { Manufacture of furniture, } \\
\text { jewellery, sports equipment and } \\
\text { toys }\end{array}$ & $36-37$ & Other manufacturing \\
\hline Electricity, gas and water supply & $40-41$ & Other manufacturing \\
\hline Construction & 45 & Other manufacturing \\
\hline
\end{tabular}




\section{$9 \quad$ References}

Adler, P.S. and S.-W. Kwon (2002), Social Capital: Prospects for a New Concept, Academy of Management Review 27 (1), 17-40.

Agrawal, A., L. Cockburn and J. McHale (2006), Gone but Not Forgotten: Knowledge Flows, Labor Mobility, and Enduring Social Relationships, Journal of Economic Geography 6 (5), 571-591.

Amit, R. and P.J.H. Schoemaker (1993), Strategic Assets and Organizational Rent, Strategic Management Journal 14 (1), 33-46.

Aschhoff, B. and T. Schmidt (2006), Empirical Evidence on the Success of R\&D CoOperation - Happy Together?, ZEW Discussion Paper No. 06-059, Mannheim.

Barney, J.B. (1991), Firm Resources and Sustained Competitive Advantage, Journal of Management 17 (1), 99-120.

Baum, J.R. and S. Wally (2003), Strategic Decision Speed and Firm Performance, Strategic Management Journal 24 (11), 1107-1129.

Bergen, M. and M.A. Peteraf (2002), Competitor Identification and Competitor Analysis: A Broad-Based Managerial Approach, Managerial \& Decision Economics 23 (4/5), 157169.

Chesbrough, H.W. (2003), Open Innovation: The New Imperative for Creating and Profiting from Technology, Boston.

Cohen, W.M. and J.P. Walsh (2000), R\&D Spillovers, Appropriability and R\&D Intensity: A Survey Based Approach.

Collis, D.J. and C.A. Montgomery (1995), Competing on Resources: Strategy in the 1990s, Harvard Business Review 73 (4), 118-128.

Conner, K.R. (1991), A Historical Comparison of Resource-Based Theory and Five Schools of Thought within Industrial Organization Economics: Do We Have a New Theory of the Firm?, Journal of Management 17 (1), 121-154.

Dierickx, I. and K. Cool (1989), Assett Stock Accumulation and Sustainability of Competitive Advantage, Management Science 35 (12), 1504-1511.

Dow, D. (2006), Adaptation and Performance in Foreign Markets: Evidence of Systematic under-Adaptation, Journal of International Business Studies 37 (2), 212-226.

Dussauge, P., B. Garrette and W. Mitchell (2000), Learning from Competing Partners: Outcomes and Durations of Scale and Link Alliances in Europe, Strategic Management Journal 21 (2), 99. 
Dyer, J.H. and H. Singh (1998), The Relational View: Cooperative Strategy and Sources of Interorganizational Competitive Advantage, Academy of Management Review 23 (4), 660-679.

Fier, A. and D. Harhoff (2002), Die Evolution Der Bundesdeutschen Forschungs- Und Technologiepolitik: Rückblick Und Bestandsaufnahme, Perspektiven der Wirtschaftspolitik 3 (3), 279-301.

Fritsch, M. and R. Lukas (2001), Who Cooperates on R \& D?, Research Policy 30 (2), 297.

Garud, R. and P.R. Nayyar (1994), Transformative Capacity: Continual Structuring by Intertemporal Technology Transfer, Strategic Management Journal 15 (5), 365-385.

Ghemawat, P. (2001), Distance Still Matters: The Hard Reality of Global Expansion, Harvard Business Review 79 (8), 137-146.

Ghemawat, P. (2003), The Forgotton Strategy, Harvard Business Review 81 (11), 76-84.

Grant, R.M. (1996), Toward a Knowledge-Based Theory of the Firm, Strategic Management Journal 17, 109-122.

Greene, W.H. (2002), Econometric Analysis, New York.

Gupta, A.K. and V. Govindarajan (2000), Knowledge Flows within Multinational Corporations, Strategic Management Journal 21 (4), 473-496.

Hamel, G. (1991), Competition for Competence and Inter-Partner Learning within International Strategic Alliances, Strategic Management Journal 12 (4), 83-103.

Hamel, G., Y.L. Doz and C.K. Prahalad (1989), Collaborate with Your Competitors -- and Win, Harvard Business Review 67 (1), 133-139.

Harvey, M. and M.M. Novicevic (2000), Staffing Global Marketing Positions: What We Don't Know Can Make a Difference, Journal of World Business 35 (1), 80.

Huston, L. and N. Sakkab (2006), Connect and Develop, Harvard Business Review 84 (3), 5866.

Hymer, S.H. (1976), The International Operations of National Firms: A Study of Direct Investment, Cambridge.

Jaffe, A.B. (1986), Technological Opportunity and Spillovers of R\&D: Evidence from Firm's Patent, Profits, and Market Value., American Economic Review 76 (5), 984-1001.

Jensen, R. and G. Szulanski (2004), Stickiness and the Adaption of Organizational Practices in Cross-Border Knowledge Transfers, Journal of International Business Studies 35 (6), 508-523.

Kaiser, U. (2002), An Emprical Test of Models Explaining Research Expenditures and Research Cooperation: Evidence for the German Service Sector, International Journal of Industrial Organization 20 (6), 747-774. 
Kalnins, A. and W. Chung (2006), Social Capital, Geography, and Survival: Gujarati Immigrant Entrepreneurs in the U.S. Lodging Industry, Management Science 52 (2), 233-247.

Keller, W. (2004), International Technology Diffusion, Journal of Economic Literature XLII (September 2004), 752-782.

Kleinschmidt, E.J. and R.G. Cooper (1988), The Performance Impact of an International Orientation of Product Innovation., European Journal of Marketing 22 (10), 56-72.

Lane, P.J., J.E. Salk and M.A. Lyles (2001), Absorptive Capacity, Learning, and Performance in International Joint Ventures, Strategic Management Journal 22 (12), 1139.

Laursen, K. and A. Salter (2006), Open for Innovation: The Role of Openness in Explaining Innovation Performance among U.K. Manufacturing Firms, Strategic Management Journal 27 (2), 131-150.

Levin, R.C., A.K. Klevorick, R.R. Nelson and S.G. Winter (1987), Appropriating the Returns from Industrial Research and Development, Brookings Papers on Economic Activity (3), 783.

Liebeskind, J.P. (1996), Knowledge, Strategy, and the Theory of the Firm, Strategic Management Journal 17, 93-107.

Lord, M.D. and A.L. Ranft (2000), Organizational Learning About New International Markets: Exploring the Internal Transfer of Local Market Knowledge, Journal of International Business Studies 31 (4), 573-589.

Luo, Y. (2004), Coopetition in International Business, Copenhagen.

Luo, Y. (2007), A Coopetition Perspective of Global Competition, Journal of World Business 42 (2007), 129-144.

Mezias, J.M. (2002), How to Identify Liabilities of Foreignness and Assess Their Effects on Multinational Corporations., Journal of International Management 8 (3), 265-283.

Nalebuff, B. and A. Brandenburger (1996), Coopetition - Kooperativ Konkurrieren, Frankfurt/Main.

Narula, R. and J. Hagedorn (1999), Innovation through Strategic Alliances: Moving Towards International Partnerships and Contractual Agreements, Technovation (19), 283-294.

Ndofor, H.A. and E. Levitas (2004), Signaling the Strategic Value of Knowledge, Journal of Management 30 (5), 685-702.

Penrose, E.T. (1959), The Theory of the Growth of the Firm, New York.

Peteraf, M.A. (1993), The Cornerstones of Competitive Advantage: A Resource Based View, Strategic Management Journal 14 (3), 179-191. 
Porter Liebeskind, J. (1997), Keeping Organizational Secrets: Protective Institutional Mechanisms and Their Costs, Industrial \& Corporate Change 6 (3), 623-663.

Priem, R.L. and J.E. Butler (2001), Is the Resource-Based 'View' a Useful Perspective for Strategic Management Research?, Academy of Management Review 26 (1), 22-40.

Rammer, C. (2002), Patente Und Marken Als Schutzmechanismen Für Innovationen, Studien Zum Deutschen Innovationssystem 11-2003, Mannheim.

Rothwell, R. and M. Dodgson (1991), External Linkages and Innovation in Small and Medium-Sized Enterprises, R\&D Management 21, 125-137.

Seung Ho, P. and M.V. Russo (1996), When Competition Eclipses Cooperation: An Event History Analysis of Joint Venture Failure, Management Science 42 (6), 875-890.

Singh, J. (2005), Collaborative Networks as Determinants of Knowledge Diffusion Patterns, Management Science 51 (5), 756-770.

Sirmon, D.G., M.A. Hitt and R.D. Ireland (2007), Managing Firm Resources in Dynamic Environments to Create Value: Looking inside the Black Box, Academy of Management Review 32 (1), 273-292.

Szulanski, G. (1996), Exploring Internal Stickiness: Impediments to the Transfer of Best Practice within the Firm, Strategic Management Journal 17 (Special issue), 27-43.

Tether, B.S. (2002), Who Co-Operates for Innovation, and Why an Empirical Analysis, Research Policy 31 (6), 948.

Veugelers, R. (1998), Collaboration in R\&D: An Assessment of Theoretical and Empirical Findings, De Economist (0013-063X) 146 (3), 419.

Wernerfelt, B. (1984), A Resource-Based View of the Firm, Strategic Management Journal 5 (2), 171-180.

West, J. and J.L. Graham (2004), A Linguistic-Based Measure of Cultural Distance and Its Relationship to Managerial Values, Management International Review 44 (2), 239260.

Zaheer, S. (1995), Overcoming the Liability of Foreignness., Academy of Management Journal 38 (2), 341-364.

Zaheer, S. (2002), The Liability of Foreignness, Redux: A Commentary, Journal of International Management 8 (3), 351-358.

Zaheer, S. and E. Mosakowski (1997), The Dynamics of the Liability of Foreignness: A Global Study of Survival in Financial Services, Strategic Management Journal 18 (6), 439-464.

Zaheer, S. and A. Zaheer (2006), Trust across Borders, Journal of International Business Studies 37 (1), 21-29. 